\title{
Epidemiology, virulence factors and management of the
}

\section{pneumococcus [version 1; peer review: 2 approved]}

\section{Charles Feldman (iD), Ronald Anderson²}

\author{
${ }^{1}$ Charlotte Maxeke Johannesburg Academic Hospital and Faculty of Health Sciences, University of the Witwatersrand Medical School, \\ Johannesburg, South Africa \\ ${ }^{2}$ Institute for Cellular and Molecular Medicine, Department of Immunology, Faculty of Health Sciences, University of Pretoria, \\ Pretoria, South Africa
}

V1 First published: 14 Sep 2016, 5(F1000 Faculty Rev):2320

https://doi.org/10.12688/f1000research.9283.1

Latest published: 14 Sep 2016, 5(F1000 Faculty Rev):2320

https://doi.org/10.12688/f1000research.9283.1

\begin{abstract}
Pneumococcal infections continue to cause significant morbidity and mortality in patients throughout the world. This microorganism remains the most common bacterial cause of community-acquired pneumonia and is associated with a considerable burden of disease and health-care costs in both developed and developing countries. Emerging antibiotic resistance has been a concern because of its potential negative impact on the outcome of patients who receive standard antibiotic therapy. However, there have been substantial changes in the epidemiology of this pathogen in recent years, not least of which has been due to the use of pneumococcal conjugate vaccines in children, with subsequent herd protection in unvaccinated adults and children. Furthermore, much recent research has led to a better understanding of the virulence factors of this pathogen and their role in the pathogenesis of severe pneumococcal disease, including the cardiac complications, as well as the potential role of adjunctive therapy in the management of severely ill cases. This review will describe recent advances in our understanding of the epidemiology, virulence factors, and management of pneumococcal community-acquired pneumonia.
\end{abstract}

\section{Keywords}

community-acquired pneumonia, adjunctive therapy , Streptococcus pneumoniae, Antibiotic resistance

\section{Open Peer Review \\ Approval Status \\ Approval Status \\ 1 \\ 2 \\ version 1 \\ 14 Sep 2016 \\ Faculty Reviews are review articles written by the prestigious Members of Faculty Opinions. The articles are commissioned and peer reviewed before publication to ensure that the final, published version is comprehensive and accessible. The reviewers who approved the final version are listed with their names and affiliations. \\ 1. Daniel Musher, Baylor College of Medicine, Houston, USA \\ Michael E. DeBakey Veterans Affairs Medical Center, Houston, USA}

2. Tobias Moser, Jena University Hospital, Jena, Germany

Any comments on the article can be found at the end of the article. 
Corresponding author: Charles Feldman (feldmanc@medicine.wits.ac.za)

Competing interests: Charles Feldman has acted on the advisory board or speakers' bureau (or both) of pharmaceutical companies manufacturing or marketing macrolide antibiotics and pneumococcal conjugate vaccines (Abbott, Aspen, Pfizer, and Sandoz). Ronald Anderson declares that he has no competing interests.

Grant information: Charles Feldman is supported by the National Research Foundation of South Africa.

The funders had no role in study design, data collection and analysis, decision to publish, or preparation of the manuscript.

Copyright: $\odot 2016$ Feldman C and Anderson R. This is an open access article distributed under the terms of the Creative Commons Attribution License, which permits unrestricted use, distribution, and reproduction in any medium, provided the original work is properly cited.

How to cite this article: Feldman $C$ and Anderson R. Epidemiology, virulence factors and management of the pneumococcus [version 1; peer review: 2 approved] F1000Research 2016, 5(F1000 Faculty Rev):2320 https://doi.org/10.12688/f1000research.9283.1

First published: 14 Sep 2016, 5(F1000 Faculty Rev):2320 https://doi.org/10.12688/f1000research.9283.1 


\section{Introduction}

Throughout most regions of the world, community-acquired pneumonia (CAP) has been documented to be associated with a significant clinical and economic burden of disease ${ }^{1-5}$. Much of this burden of disease is due to Streptococcus pneumoniae (pneumococcus), since this microorganism is regularly documented to be the most common bacterial cause of CAP in the vast majority of studies ${ }^{1-5}$. The purpose of this article, which is largely an update of a similar one published in $2014^{6}$, is to review the latest information regarding the epidemiology, virulence factors and management of pneumococcal disease, with a particular focus on pneumococcal pneumonia.

\section{Epidemiology of pneumococcal disease}

\section{The burden of pneumococcal pneumonia}

Pneumococcal infections are characterized as being invasive or non-invasive ${ }^{7}$. Invasive pneumococcal disease includes meningitis and bacteremia, and non-invasive disease includes otitis media and sinusitis. With regard to pneumococcal pneumonia specifically, these infections may be either invasive (bacteremic) or non-invasive (non-bacteremic) ${ }^{7}$. A systematic review and metaanalysis of the literature that provided data on the yield of the various diagnostic techniques available for confirming the presence of pneumococcal pneumonia clearly indicated that the true burden of disease is considerably underestimated when these assessments are based on data from bacteremic infections alone ${ }^{8}$. In fact, it has been said that for every case of bacteremic pneumococcal CAP there are approximately three additional cases of non-bacteremic pneumonia. Non-bacteremic pneumonia represents the largest burden of pneumococcal infection in adults ${ }^{7}$ and therefore is the focus of the present review.

\section{The role of Streptococcus pneumoniae in the etiology of community-acquired pneumonia}

A number of studies from Europe, including a recent literature review, while noting that the prevalence of $S$. pneumoniae in CAP does vary in different regions and in different clinical settings, indicated that this microorganism was the most commonly isolated pathogen in patients with $\mathrm{CAP}^{9}$. Furthermore, in that literature review, the frequency of isolation of $S$. pneumoniae was higher in patients who were at least 65 years old than in younger adults, and $S$. pneumoniae remained the most common isolate in patients who were HIV-infected and in those cases who had chronic obstructive pulmonary disease (COPD). In another systematic review and meta-analysis investigating the role of $S$. pneumoniae in CAP, this microorganism was more likely to be detected in studies in which polymerase chain reaction assays were performed for diagnostic purposes, and also in studies including intensive care unit (ICU) cases compared with that observed in hospitaltreated patients or outpatients ${ }^{10}$. Other studies from Europe have also concluded that the pneumococcus is the most commonly isolated pathogen in CAP, being a cause of $35 \%$ of cases overall ${ }^{7}$. Additional studies have also reported that the pneumococcus was the most common pathogen irrespective of whether the patients were treated in the outpatient, inpatient or hospital settings, including younger patients and even cases with nursing home-acquired pneumonia ${ }^{7}$. A study from the German Network for Community-acquired Pneumonia (CAPNETZ) investigating 7,400 cases from 12 clinical centers documented a pathogen in $32 \%$ of the patients with CAP, and among the latter cases the pneumococcus was the most commonly isolated pathogen (30\% of patients) ${ }^{11}$. Compared with patients with non-pneumococcal infections, those with pneumococcal pneumonia were more likely to be admitted to hospital, to have a higher CURB-65 score (confusion of new onset [abbreviated mental test score of 8 or less], blood urea nitrogen of greater than $7 \mathrm{mmol} / \mathrm{l}(19 \mathrm{mg} / \mathrm{dl})$, respiratory rate of 30 breaths per minute or greater, systolic blood pressure of less than $90 \mathrm{~mm} \mathrm{Hg}$ or diastolic blood pressure of $60 \mathrm{~mm} \mathrm{Hg}$ or less, and age of at least 65 years), and to have a pleural effusion more frequently as well as a need for mechanical ventilation and oxygen therapy ${ }^{11}$.

Two recent studies, which included data on microbial etiology, were reported from the US among adults hospitalized with $\mathrm{CAP}^{12,13}$. In both studies, rhinovirus was the most common isolate. In the first study, which included both invasive and non-invasive cases, the pneumococcus was the second most common isolate, representing $18.5 \%$ of cases in which an etiological agent was identified $^{12}$. The second study, despite an extensive microbiological investigation which included molecular diagnostic testing, documented a pathogen in only $38 \%$ of cases ( 853 out of 2,259 patients $)^{13}$. The pneumococcus was the third most common isolate, being documented in $5 \%$ of patients. However, the authors conceded that there may be a number of reasons for the low yield of pathogens despite a comprehensive diagnostic approach, including an inability to obtain adequate lower respiratory tract samples, antibiotic exposure prior to diagnostic testing, and insensitivity of diagnostic tests for known pathogens ${ }^{13}$. Furthermore, not all eligible patients were enrolled, those who were at least 65 years old and/or were undergoing mechanical ventilation were less likely to be enrolled and not all enrolled patients had all diagnostic studies done. The authors also suggested that the low yield specifically of pneumococcal isolates may also relate to the indirect effects ("herd protection") of pediatric pneumococcal vaccination.

\section{Antibiotic resistance in pneumococcal community-acquired pneumonia isolates}

Antibiotic resistance is known to be an important issue in pneumococcal infections ${ }^{14,15}$, and in the literature review described above, penicillin resistance was variably reported in $14.9 \%$ to $25.7 \%$ and erythromycin resistance in $12.0 \%$ to $21 \%$ of pneumococcal isolates causing $\mathrm{CAP}^{9}$. Penicillin resistance in pneumococci is defined by the minimum inhibitory concentration (MIC) breakpoints that are determined by the Clinical and Laboratory Standards Institute (CLSI) and the European Committee on Antimicrobial Susceptibility Testing (EUCAST) ${ }^{16}$. The classic CLSI MIC breakpoints, established to prevent likely treatment failures in pneumococcal meningitis, defined penicillin-susceptible pneumococcal isolates as those having an MIC of not more than $0.06 \mathrm{mg} / \mathrm{l}$, intermediate resistance strains as those having an MIC of between 0.12 and $1 \mathrm{mg} / \mathrm{l}$, and resistance strains as those having an MIC of at least $2 \mathrm{mg} / \mathrm{l}$. These MIC levels are still considered appropriate for the evaluation of meningitis treatment and possibly oral treatment of non-meningeal pneumococcal infections. However, for parenteral treatment of pneumococcal pneumonia, the breakpoints now considered appropriate are an MIC for susceptible strains of $2 \mathrm{mg} / \mathrm{l}$ or less, for intermediate strains of $4 \mathrm{mg} / \mathrm{l}$ and for resistant strains of $8 \mathrm{mg} / \mathrm{l}$ or more ${ }^{16}$. 
Macrolide resistance is predominantly due to either an efflux pump mechanism, which tends to be associated with lower levels of macrolide resistance and is common in North America, or a ribosomal methylation mechanism that tends to be associated with higher levels of macrolide resistance and is more common in Europe ${ }^{16}$. Pathogens with both mechanisms of resistance are also emerging.

However, there has been considerable debate as to whether current prevalence and levels of resistance have a true impact on the outcome of patients who receive standard guideline-compliant therapy, particularly with regard to the macrolide group of antibiotics $^{14,16-19}$. In pneumococcal pneumonia, as opposed to meningitis, there is considerably less concern, in general, with regard to beta-lactam resistance because of the high levels that the commonly used antibiotics can achieve in blood and tissues, and the only concern is in the case of isolates with very high $\mathrm{MICs}^{20}$. These, fortunately, remain rather uncommon at the current time in both Europe ${ }^{21}$ and the US ${ }^{22}$, and in some studies their numbers have actually decreased in both children and adults following the introduction of the pneumococcal conjugate vaccine (PCV) in children. However, researchers have certainly voiced concern about escalating levels of macrolide resistance, citing evidence of failure of macrolide therapy in cases with both low-level and high-level macrolide resistance, and have therefore indicated that macrolide monotherapy for CAP may not be appropriate ${ }^{16,17}$. One study investigating the effects of macrolide resistance on presentation of pneumococcal pneumonia and its outcome indicated that patients with macrolide-resistant $S$. pneumoniae infections were not more severely ill compared with those with antibioticsusceptible infections, nor did they have worse clinical outcomes ${ }^{18}$. Thus, it is widely recommended that macrolides still be used routinely in CAP, generally as part of combination therapy for patients with severe CAP and sepsis (see antibiotic treatment) ${ }^{19}$. It is important to reflect on the fact that implementation of the PCVs in children, which is discussed in more detail below, has had a significant impact on the occurrence of drug-resistant pneumococcal infections in both children and adults ${ }^{20,22}$.

Invasive pneumococcal disease

It has been said that pneumococcal pneumonia is associated with bacteremia (invasive pneumococcal pneumonia, or IPD) in approximately $10 \%$ to $30 \%$ of cases ${ }^{14}$. Before the widespread introduction of the PCVs in children-with subsequent "herd protection" which was associated with a decreased incidence of pneumococcal infections even in unvaccinated children and adults-the rates of incidence of IPD in Europe and the US were reported as being between 11 and 49 cases per 100,000 population $^{7,14}$ and between 16.2 and 59.7 out of 100,000 in adults more than 65 years old ${ }^{14}$. The incidence was considerably higher in cases with underlying co-morbid conditions (176 to 483 cases per 100,000 population) and highest in those with underlying immunosuppression (342 to 2,031 per 100,000 population) ${ }^{14}$. The incidence of IPD is affected by many factors, including the use of pneumococcal vaccination in children and in adults through direct or herd protection (or both) ${ }^{7}$. Considerable reductions in the rate of vaccinetype IPD have been documented in all ages following introduction of the PCVs in childhood programs, particularly in the US ${ }^{23}$. Sustained declines in hospitalizations for CAP in both children and adults were documented in the US following the introduction of $\mathrm{PCV}^{24}$, and early data have shown similar further benefits with the introduction of PCV13, not only in vaccinated children but also in at least some of the adult age groups ${ }^{25}$.

However, some European studies, particularly those in France, have indicated an increase in the incidence of IPD in adults, particularly in cases with underlying risk factors, which have been ascribed to various possibilities including differences in vaccine coverage compared with that of the US, fluctuations in serotypes, and possible outbreaks of infection ${ }^{7,26}$. Certainly, following introduction of PCV7, many, but not all, studies documented the occurrence of serotype replacement disease ${ }^{27}$. This was an increase in invasive pneumococcal infections due to non-vaccine serotypes, in particular 19A, but including other serotypes, occurring in both children and non-vaccinated adults ${ }^{27}$. The magnitude of the replacement in non-vaccinated groups varied, and some areas reported complete serotype replacement, indicating no net change in overall IPD incidence, whereas other areas reported very little serotype replacement ${ }^{27}$. Subsequently, PCV7 use in children was largely replaced by PCV13, the latter also covering for serotype 19A, and while a similar reduction in vaccine-type IPD was also documented, as with PCV7, serotype replacement disease is once again being documented ${ }^{28,29}$.

Whereas a study from England and Wales showed a reduction in IPD following introduction of the conjugate vaccines with substantial herd protection initially from PCV7 and extending subsequently to $\mathrm{PCV} 13^{30}$, an additional study in adults from the UK indicated that although reductions in pneumococcal infections have occurred in adults (in association with herd protection), vaccine-type pneumococcal disease continues to have a high burden of disease in adults in that country ${ }^{31}$.

\section{Risk factors for pneumococcal infections}

Although a detailed description of risk factors that increase the incidence of pneumococcal infections is beyond the scope of the present review and has been extensively reviewed elsewhere ${ }^{32,33}$, some pertinent or recent studies (or both) need specific mention. It is clearly indicated that although immunosenescence, which is age-related deterioration in host immune responses in the elderly, is well recognized as a risk factor for infections in general, it is poorly understood and is often undetected ${ }^{34}$. Cigarette smoking is recognized to be one of the most important independent risk factors for IPD among immunocompetent non-elderly adults ${ }^{35}$, such that smoking strategies have the potential to reduce the risk of IPD significantly. In addition, recent data have suggested that current smokers with pneumococcal pneumonia have an increased risk of severe sepsis, require hospitalization at a younger age, despite fewer comorbidities, and have an increased risk of 30-day mortality independent of age and comorbidity ${ }^{36}$. HIV infection, as a risk factor for pneumococcal infections, is also well characterized ${ }^{37}$. Recent systematic literature reviews from Europe and Canada have confirmed the importance of various lifestyle and comorbid conditions-including smoking, alcohol abuse, being underweight, poor dental hygiene, chronic respiratory conditions such as COPD and asthma, diabetes mellitus, chronic heart disease, chronic liver disease, cerebrovascular disease, Parkinson's disease, epilepsy, dementia, dysphagia, and chronic renal and liver disease-as risk factors for pneumococcal CAP $\mathrm{CA}^{11,38-40}$. 


\section{Pneumococcal virulence}

This section covers recently described roles for established pneumococcal virulence factors-specifically the cholesterolbinding, pore-forming toxin, pneumolysin (Ply); the adhesin, choline-binding protein A $(\mathrm{CbpA})$; and hydrogen peroxide $\left(\mathrm{H}_{2} \mathrm{O}_{2}\right)$ - as well as a brief overview of novel virulence factors, some with vaccine potential, not included in our previous reviews $\mathrm{s}^{6,41,42}$. This is preceded by a consideration of the emerging threat posed by non-encapsulated strains of the pneumococcus coincident with the widespread inclusion of PCVs in national childhood immunization programs.

\section{Non-encapsulated Streptococcus pneumoniae}

The polysaccharide capsule of the pneumococcus is widely recognized as being the major virulence determinant of this bacterial pathogen and accordingly the primary target for vaccine design. Though efficacious, capsular polysaccharide-based vaccines have two significant limitations: firstly, the restricted immunogenicity of the capsular polysaccharides, which results in direct activation of B cells without the involvement of T-cell help, which can be overcome by conjugation to a protein carrier, and, secondly, the large number of pneumococcal capsule structural variants, known as serotypes. Based on conventional serotyping procedures, complemented by molecular analyses, at least 97 different serotypes of the pneumococcus have been identified ${ }^{43}$. Consequently, the number of different capsular polysaccharides contained in pneumococcal vaccines is limited to those serotypes most frequently associated with severe disease ${ }^{42}$.

Two types of pneumococcal vaccines are currently licensed for use in humans and vary with respect to design, composition, target populations, immunogenicity and efficacy. These are pneumococcal polysaccharide vaccine 23 (PPV3) and several types of $\mathrm{PCV}^{42}$. PPV23, licensed in the US in 1983, consists of capsular polysaccharides derived from 23 different serotypes of the pneumococcus, which collectively account for $85 \%$ to $90 \%$ of cases of IPD ${ }^{42,44}$.

The first PCV, PCV7, was licensed in the US in 2000 but has been superseded by PCV13, which consists of 13 capsular polysaccharides, derived from the most common disease-causing serotypes of the pneumococcus. Relative to PPV23, PCVs have markedly improved immunogenicity in neonates and young children. This has resulted in their widespread and successful inclusion in the national childhood immunization programs of many developed and developing countries ${ }^{24,30,45-57}$. Importantly, unlike PPV23, PCVs do counter nasopharyngeal carriage of vaccine strains of the pneumococcus, resulting in induction of indirect immunity, also known as herd immunity, as mentioned above, thereby conferring secondary protection on adults ${ }^{24,30,49,50,53,56,57}$.

Despite their undoubted impact in preventing IPD across all age groups (vaccinated and non-vaccinated), PCVs do have limitations, as alluded to above. Notwithstanding an increased frequency of nasopharyngeal colonization by non-vaccine serotypes of the pneumococcus, the global implementation of PCV13 and its forerunners in national childhood immunization programs has also been accompanied by the emergence of non-encapsulated strains of the pathogen ${ }^{58}$. These have been reported to account for an estimated $3 \%$ to $19 \%$ of asymptomatic carriage isolates, with the lower figure possibly representing a more realistic estimate ${ }^{58}$.
Though somewhat less virulent than their encapsulated counterparts, these non-encapsulated strains of the pneumococcus nevertheless have a significant association with non-invasive infections, such as conjunctivitis and otitis media, as well as with IPD, albeit at a lower prevalence ${ }^{58}$.

In addition to anti-phagocytic activity, the polysaccharide capsule plays a role in nasopharyngeal colonization by enabling the pathogen to evade attachment to airway mucus, thereby interfering with expulsion of the pathogen by the mucociliary escalator ${ }^{59}$. However, a reduction in capsule size is necessary to expose the various underlying protein adhesins which mediate attachment to respiratory epithelium, a prerequisite for robust colonization and invasion $^{60}$. Loss of the polysaccharide capsule appears to involve repression of the genes involved in capsule production which reside in a single cluster known as the $c p s$ locus ${ }^{58,61}$. However, mutations or deletions of $c p s$ genes may result in the emergence of non-encapsulated strains of the pneumococcus ${ }^{58}$.

The loss of the capsule in non-encapsulated strains of the pneumococcus, however, is counter-balanced by the acquisition of a range of compensatory virulence mechanisms, some unique and others related to increased expression of existing mechanisms. Foremost in the former category is expression of the novel adhesin, pneumococcal surface protein $\mathrm{K}$ (PspK), encoded by the cps replacement gene, $p s p K$, which has been described in a nonencapsulated subtype of the pneumococcus ${ }^{58,60}$. PspK promotes adhesion of the non-encapsulated pathogen to the respiratory epithelium of the host, albeit by poorly characterized mechanisms, which nonetheless appear to contribute to nasopharyngeal colonization $58,60,62,63$. In addition, PspK may contribute to the virulence of non-encapsulated pneumococci by binding to, and neutralizing, secretory $\operatorname{IgA}$ on mucosal surfaces ${ }^{58,62}$.

Increased production of biofilm by non-encapsulated strains of the pneumococcus, also favoring colonization or virulence (or both), is another mechanism which distinguishes these strains from their capsulated counterparts ${ }^{58,64}$. Biofilm is a self-generated, polymer matrix which insulates the pathogen against host defenses and antimicrobial agents, enabling it to remain quiescent, re-emerging when the host environment is less hostile. In this context, it is noteworthy that acquisition of the non-encapsulated phenotype in a $\operatorname{csp} E$ gene mutant of serotype $18 \mathrm{C}$ of the pneumococcus was found to be associated with increased expression of six early competence pathway genes involved in DNA binding, uptake and recombination, as well as of one competence-pathway-associated gene, the expression levels of these being 11- to 34-fold higher than the wild-type encapsulated variant ${ }^{65}$. The $\operatorname{csp} E$ gene encodes a glycosyltransferase enzyme which catalyses the first step in capsule formation ${ }^{58,65}$. In addition to involvement in biofilm formation, increased expression of competence genes was associated with increased growth, a 117-fold increase in adhesion to nasopharyngeal epithelial cells, and enhanced genetic transformability ${ }^{65}$; the last of these probably underpins the higher rates of antibiotic resistance reported in non-encapsulated strains of the pathogen ${ }^{58}$.

Notwithstanding the remarkable impact of PVCs in particular, the emerging threats posed by nasopharyngeal colonization with non-vaccine serotypes and non-encapsulated strains of the pneumococcus clearly underscore the need for future generation 
pneumococcal vaccines designed to provide much broader protective coverage. In this context, non-encapsulated whole cell vaccines which express immunogenic proteins, adhesins, or attenuated virulence factors common to capsulated and non-encapsulated strains of the pneumococcus (or both) are currently in the developmental pipeline ${ }^{42}$. Alternatives include vaccines consisting of recombinant proteins expressed by both types of the pneumococcus $^{42}$. These novel vaccines are likely to complement PCVs rather than replace them. In this context, however, it is noteworthy that non-encapsulated strains of the pneumococcus may not express two of the major protein vaccine candidates, PspA and PspC, expressed by encapsulated strains ${ }^{58}$.

\section{Novel roles in tissue injury for established pneumococcal virulence factors}

The association between pneumococcal pneumonia and acute cardiac events was first described by Musher et al. in $2007^{66}$. These authors reported that "patients with pneumococcal pneumonia are at substantial risk for a concurrent acute cardiac event such as myocardial infarction, serious arrhythmia, or new or worsening congestive heart failure" ${ }^{66}$. It is only fairly recently, however, that significant insights into the pathophysiology of myocardial damage associated with IPD have emerged following the publication of data derived from two independent experimental animal studies.

In the first of these, Brown et al. reported on the occurrence of invasion of the myocardium during experimental pneumococcal infection of mice and rhesus macaques ${ }^{67}$. Myocardial invasion was dependent on the expression of two pneumococcal adhesins, CbpA and cell wall phosphorylcholine expressed on the lipoteichoic acid backbone, which interact with laminin receptors on vascular endothelial cells and the platelet-activating factor receptor, respectively ${ }^{67-69}$. Invasion of the myocardium resulted in the development of cardiac microlesions and myocardial damage due predominantly to the cytotoxic actions of Ply. These findings were supported by observations of similar microlesions in cardiac sections from patients who had succumbed to IPD ${ }^{67}$. In addition, a subsequent study by Alhamdi et al. confirmed the critical involvement of Ply in the pathogenesis of cardiac injury in a murine model of experimental $\mathrm{IPD}^{70}$. Notable differences between the studies by Brown et al. ${ }^{67}$ and Alhamdi et al..$^{70}$ include the apparent lack of involvement of $\mathrm{CbpA}$ and cardiac colonization in the latter study, in which circulating Ply appeared to be the sole mediator of myocardial damage.

Additional mechanisms by which Ply may promote cardiotoxicity in IPD include secondary cytotoxicity due to release of histones from dead and dying cardiomyocytes and other types of bystander cells $^{71}$. In addition, Ply has been reported to activate platelet aggregation in vitro, which, if operative in vivo, may also contribute to myocardial dysfunction via platelet plug formation and microvascular damage ${ }^{72,73}$.

In a more recent study, Gilley et al., while confirming the involvement of Ply in the pathogenesis of cardiac microlesions in a murine model of experimental IPD, also reported that Ply induces a type of inflammatory cell death known as necroptosis in infiltrated macrophages, possibly contributing to persistence of the pneumococcus $^{74}$. In addition, and in contradistinction to the earlier studies ${ }^{67,70}$, these authors reported that cardiac invasion by a Ply-deficient mutant of the pneumococcus also resulted in the formation of microlesions. Although the exact pneumococcal cytotoxins involved in this type of Ply-independent cardiotoxicity were not identified, the authors speculated that $\mathrm{H}_{2} \mathrm{O}_{2}$ produced via the activity of pneumococcal pyruvate oxidase may be implicated. In this context, low and high concentrations of $\mathrm{H}_{2} \mathrm{O}_{2}$ induce apoptosis and necroptosis, respectively, in eukaryotic cells ${ }^{75,76}$. The pneumococcus, which is a catalase-negative microorganism, appears to protect itself against both self-and host-generated extracellular $\mathrm{H}_{2} \mathrm{O}_{2}$ through the surface expression of the anti-oxidative, thioredoxinfold lipoproteins Etrx1 and 2, as well as the detoxifying enzyme methionine sulfoxide reductase $(S p M s r A B 2)^{77}$. Ply in particular and possibly also $\mathrm{H}_{2} \mathrm{O}_{2}$ appear to represent important targets in the prevention of cardiac sequelae in patients with IPD.

\section{Novel pneumococcal virulence factors}

This section is a brief summary of novel pneumococcal virulence factors published since our last review of these in $2014^{42}$. They are summarized in Table 1 together with the relevant references ${ }^{78-85}$. These clearly reinforce the already impressive armamentarium of virulence factors used by the pneumococcus.

\section{Antibiotic and adjunctive therapy}

Several recent studies have described the optimal antibiotic management of patients with CAP, including pneumococcal CAP, in both hospitalized (including ICU cases) and non-hospitalized patients, and these have largely confirmed previous findings. One recent randomized study, largely in non-severely ill patients (mean pneumonia severity index [PSI] score of 84), indicated that in non-severely ill cases, (PSI I to III) but not in severely ill cases (PSI IV), beta-lactam monotherapy was non-inferior to a beta-lactam-macrolide combination ${ }^{86}$. However, there was a nonsignificant trend to superiority of combination therapy, and the 30 -day readmission rate was higher in the monotherapy $\operatorname{arm}^{86}$. A more recent systematic literature review indicated that the lowest short-term mortality in patients with CAP was associated with the early initiation ( 4 to 8 hours) of a beta-lactam-macrolide combination or fluoroquinolone monotherapy ${ }^{87}$. However, a further study in the ICU setting indicated that the combination therapy was associated with a lower mortality than the monotherapy and was associated with better outcomes, though not necessarily decreased mortality, in patients not requiring ICU admission but with risk factors for a poor outcome and in bacteremic pneumococcal infections ${ }^{88}$. The same authors documented both in severe pneumococcal pneumonia and in severe non-pneumococcal pneumonia that early administration of antibiotics and combination antibiotic therapy was associated with improved ICU survival ${ }^{89,90}$. These studies complement the findings of a systematic review and meta-analysis of critically ill patients with CAP which documented that macrolide-containing regimens were associated with a reduced mortality compared with the use of non-macrolide-containing antibiotic regimens ${ }^{91}$. A number of recent reviews have reinforced the importance of macrolide combination antibiotic therapy on the outcome of CAP, particularly among severely ill patients with CAP, highlighting the relative safety of use of these agents, even in elderly patients, while reaffirming the likely importance of the immunomodulatory effects of these agents ${ }^{92-94}$. 


\begin{tabular}{|c|c|c|c|}
\hline Virulence factor & Function & Outcome & Reference \\
\hline $\begin{array}{l}\text { PbIB (cell wall, phage-encoded } \\
\text { platelet-binding protein) }\end{array}$ & $\begin{array}{l}\text { Pro-adhesive, also binds to galactose- } \\
\text { containing residues on lung epithelium }\end{array}$ & $\begin{array}{l}\text { Promotes nasopharyngeal } \\
\text { colonization }\end{array}$ & 78 \\
\hline DiiA (cell wall protein) & Pro-adhesive, binds to collagen and lactoferrin & $\begin{array}{l}\text { Promotes nasopharyngeal } \\
\text { colonization and } \\
\text { dissemination }\end{array}$ & 79 \\
\hline $\begin{array}{l}\text { GH20C (a novel, presumably cell } \\
\text { wall, } \beta \text {-hexosamidase) }\end{array}$ & $\begin{array}{l}\text { Involved in nutrient acquisition by processing } \\
\text { hexosaminide sugars from host glycans }\end{array}$ & $\begin{array}{l}\text { Promotes growth and } \\
\text { persistence }\end{array}$ & 80 \\
\hline $\begin{array}{l}\text { Bg1A3 (a cell membrane } \\
6 \text {-phospho- } \beta \text {-glucosidase) }\end{array}$ & $\begin{array}{l}\text { Converts phosphorylated substrates to usable, } \\
\text { nutrient monosaccharides }\end{array}$ & $\begin{array}{l}\text { Promotes survival and } \\
\text { virulence }\end{array}$ & 81 \\
\hline $\begin{array}{l}\text { Spbhp-37 (cell wall hemoglobin- } \\
\text { binding protein) }\end{array}$ & Iron acquisition & Growth and infectivity & 82 \\
\hline $\begin{array}{l}\text { Elongation factor Tu (Tuf), a protein } \\
\text { with both cytoplasmic and cell } \\
\text { surface locations }\end{array}$ & $\begin{array}{l}\text { Binds inactivators of the complement systems } \\
\text { (Factor } \mathrm{H} \text { and complement Factor } \mathrm{H} \text {-related } \\
\text { protein 1) preventing complement-mediated } \\
\text { attack }\end{array}$ & Immune evasion, virulence & 83 \\
\hline Polyamine transporter, potABCD & $\begin{array}{l}\text { Promotes uptake of polyamines which protect } \\
\text { against acid and reactive oxygen species and } \\
\text { promotes biofilm formation }\end{array}$ & Immune evasion, virulence & 84 \\
\hline $\begin{array}{l}\text { L-Ascorbate-6-phosphate } \\
\text { lactonase, a protein with a cell } \\
\text { membrane location }\end{array}$ & $\begin{array}{l}\text { Highly conserved enzyme with metallo- } \beta \text { - } \\
\text { lactamase activity }\end{array}$ & $\begin{array}{l}\text { Possible contributor to } \\
\beta \text {-lactam antibiotic resistance }\end{array}$ & 85 \\
\hline
\end{tabular}

Since the mortality of patients with CAP remains substantial despite appropriate antibiotic use, a number of adjunctive therapies have been recommended for severely ill patients with CAP in an attempt to improve the outcome ${ }^{6,95,96}$. Macrolide antibiotics may be considered to have both antimicrobial and adjunctive effects, the latter because of their immunomodulatory properties, which have recently been reviewed ${ }^{93,97}$. Among the other putative adjunctive therapies, corticosteroids currently appear to be the most promising agents on the basis of a number of recent studies and meta-analyses ${ }^{98-100}$. Statins and antiplatelet agents appear to be interesting because of the particular role they may play in preventing the occurrence of cardiovascular events in patients with CAP, whereas a myriad of other agents have also been mentioned, the potential benefits of which have been reviewed elsewhere $^{95,96,101}$.

\section{Mortality}

It is interesting to reflect on the fact that despite medical advances, the case fatality rate for patients hospitalized with IPD has remained relatively constant over the past 60 years ${ }^{102}$ and that the mortality of patients with pneumococcal CAP, even among patients admitted to the ICU, remains high despite appropriate antibiotic treatment ${ }^{103}$. There has been much ongoing debate as to the relative impact of host factors, versus pneumococcal serotype/ antibiotic therapy on the outcome of pneumococcal CAP ${ }^{104}$. With regard to respiratory failure, which is said to be a frequent complication of pneumococcal pneumonia, certain serotypes are the main risk factors (serotypes 3, 19A and 19F) ${ }^{105}$. However, several other studies attest to the importance of host factors, as predictors of mortality, including lifestyle factors such as alcohol use disorders ${ }^{106}$, tobacco smoking ${ }^{36}$, advanced age ${ }^{104,107}$, and underlying comorbidities both in hospitalized patients and in patients admitted to the $\mathrm{ICU}^{104,108}$. Interestingly, in contrast to studies mentioned above, one recent study suggested that current smoking was associated with a lower mortality in bacteremic pneumococcal pneumonia since these individuals were more likely to be infected with serotypes associated with a low case fatality rate ${ }^{109}$. A number of additional studies, some described above, have indicated that there has been a declining mortality in adults with pneumococcal infections, mainly in the age group of 18 to 64 years, as a consequence of herd protection afforded by childhood vaccination with the PCVs ${ }^{110}$.

\section{Conclusions}

Despite very substantial advances in diagnosis, therapy and ICU care, the outcome of patients with IPD, particularly the elderly and those with other associated risks, has remained essentially unchanged for several decades, even in the setting of seemingly appropriate antimicrobial therapy. This has led to a heightened awareness of the existence of sub-groups of patients at particularly high risk for the development of life-threatening complications, including acute lung injury and acute cardiovascular events, who are likely to benefit most from early, aggressive antibiotic therapy, as well as discerning administration of adjunctive, antiinflammatory therapies. Targeting high-risk sub-groups would be most efficacious if undertaken in the setting of access to rapid, reliable molecular diagnostics, together with identification of those host-derived systemic biomarkers of inflammation and tissue damage which accurately predict type of complication and outcome. With respect to prevention, dual influenza and pneumococcal immunization, particularly for the elderly, is strongly recommended.

In addition, the efficacy of current vaccines may be enhanced through the development of novel "hybrid" vaccines in which capsular polysaccharides are combined with highly conserved, 
immunogenic, pneumococcal proteins, shared by capsulated and non-encapsulated strains, thereby conferring much broader coverage, including protection against non-vaccine serotypes and non-encapsulated strains of the pneumococcus.

\section{Abbreviations}

CAP, community-acquired pneumonia; CbpA, choline-binding protein A; CLSI, Clinical and Laboratory Standards Institute; COPD, chronic obstructive pulmonary disease; $\mathrm{H}_{2} \mathrm{O}_{2}$, hydrogen peroxide; ICU, intensive care unit; IPD, invasive pneumococcal disease; MIC, minimum inhibitory concentration; PCV, pneumococcal conjugate vaccine; Ply, pneumolysin; PPV, pneumococcal polysaccharide vaccine; PSI, pneumonia severity index; PspK, pneumococcal surface protein $\mathrm{K}$.

\section{Competing interests}

Charles Feldman has acted on the advisory board or speakers' bureau (or both) of pharmaceutical companies manufacturing or marketing macrolide antibiotics and pneumococcal conjugate vaccines (Abbott, Aspen, Pfizer, and Sandoz). Ronald Anderson declares that he has no competing interests.

\section{Grant information}

Charles Feldman is supported by the National Research Foundation of South Africa.

The funders had no role in study design, data collection and analysis, decision to publish, or preparation of the manuscript.
1. File TM Jr, Marrie TJ: Burden of community-acquired pneumonia in North American adults. Postgrad Med. 2010; 122(2): 130-41. PubMed Abstract | Publisher Full Text

2. Isturiz RE, Luna CM, Ramirez J: Clinical and economic burden of pneumonia among adults in Latin America. Int J Infect Dis. 2010; 14(10): e852-6. PubMed Abstract | Publisher Full Text

3. Shibl AM, Memish ZA, Ibrahim E, et al.: Burden of adult community-acquired pneumonia in the Middle East/North Africa region. Rev Med Microbiol. 2010; 21(1): 11-20.

Publisher Full Text

4. Song JH, Thamlikitkul V, Hsueh PR: Clinical and economic burden of communityacquired pneumonia amongst adults in the Asia-Pacific region. Int $J$ Antimicrob Agents. 2011; 38(2): 108-17.

PubMed Abstract | Publisher Full Text

5. Welte T, Torres A, Nathwani D: Clinical and economic burden of communityacquired pneumonia among adults in Europe. Thorax. 2012; 67(1): 71-9. PubMed Abstract | Publisher Full Text

6. Feldman $C$, Anderson R: Recent advances in our understanding of Streptococcus pneumoniae infection. F1000Prime Rep. 2014; 6: 82 PubMed Abstract | Publisher Full Text | Free Full Text

7. Drijkoningen JJ, Rohde GG: Pneumococcal infection in adults: burden of disease Clin Microbiol Infect. 2014; 20(Suppl 5): 45-51. PubMed Abstract | Publisher Full Text

8. F Said MA, Johnson HL, Nonyane BA, et al.: Estimating the burden of pneumococcal pneumonia among adults: a systematic review and metaanalysis of diagnostic techniques. PLoS One. 2013; 8(4): e60273. analysis of diagnostic techniques. PLoS One. 2013; 8(4): e60273.
PubMed Abstract | Publisher Full Text | Free Full Text | F1000 Recommendation

9. Torres A, Blasi F, Peetermans WE, et al.: The aetiology and antibiotic management of community-acquired pneumonia in adults in Europe: a literature review. Eur J Clin Microbiol Infect Dis. 2014; 33(7): 1065-79. PubMed Abstract | Publisher Full Text | Free Full Text

10. Rozenbaum MH, Pechlivanoglou P, van der Werf TS, et al.: The role of Streptococcus pneumoniae in community-acquired pneumonia among adults in Europe: a meta-analysis. Eur J Clin Microbiol Infect Dis. 2013; 32(3): 305-16. PubMed Abstract | Publisher Full Text

11. Pletz MW, von Baum $\mathrm{H}$, van der Linden $\mathrm{M}$, et al:: The burden of pneumococcal pneumonia - experience of the German competence network CAPNETZ Pneumologie. 2012; 66(8): 470-5. PubMed Abstract | Publisher Full Tex

12. Musher DM, Roig IL, Cazares G, et al:: Can an etiologic agent be identified in adults who are hospitalized for community-acquired pneumonia: results of a one-year study. J Infect. 2013; 67(1): 11-8. PubMed Abstract | Publisher Full Text

13. F Jain S, Self WH, Wunderink RG, et al:: Community-Acquired Pneumonia Requiring Hospitalization among U.S. Adults. N Engl J Med. 2015; 373(5): 415-27. PubMed Abstract | Publisher Full Text | Free Full Text | F1000 Recommendation

14. Blasi $F$, Mantero M, Santus $P$, et al.: Understanding the burden of pneumococcal disease in adults. Clin Microbiol Infect. 2012; 18(Suppl 5): 7-14. PubMed Abstract | Publisher Full Text

15. Ash SY, Sheffield JV: Pneumococcus. Med Clin North Am. 2013; 97(4): 647-66, $\mathrm{x}-\mathrm{xi}$. PubMed Abstract | Publisher Full Text
16. Cilloniz C, Ardanuy C, Vila J, et al:: What is the clinical relevance of drug-resistant pneumococcus? Curr Opin Pulm Med. 2016; 22(3): 227-34. PubMed Abstract | Publisher Full Text

17. Low DE: What is the relevance of antimicrobial resistance on the outcome of community-acquired pneumonia caused by Streptococcus pneumoniae? (should macrolide monotherapy be used for mild pneumonia?). Infect Dis Clin North Am. 2013; 27(1): 87-97. PubMed Abstract | Publisher Full Text

18. F Cilloniz C, Albert RK, Liapikou A, et al.: The Effect of Macrolide Resistance on the Presentation and Outcome of Patients Hospitalized for Streptococcus pneumoniae Pneumonia. Am J Respir Crit Care Med. 2015; 191(11): 1265-72. PubMed Abstract | Publisher Full Text | F1000 Recommendation

19. Niederman MS: Macrolide-Resistant Pneumococcus in Community-acquired Pneumonia. Is There Still a Role for Macrolide Therapy? Am J Respir Crit Care Med. 2015; 191(11): 1216-7. PubMed Abstract | Publisher Full Text

20. Kim L, McGee L, Tomczyk S, et al: Biological and Epidemiological Features of Antibiotic-Resistant Streptococcus pneumoniae in Pre- and Post-Conjugate Vaccine Eras: a United States Perspective. Clin Microbiol Rev. 2016; 29(3): $525-52$.

PubMed Abstract | Publisher Full Text | Free Full Text

21. Imöhl M, Reinert RR, van der Linden M: Antibiotic susceptibility rates of invasive pneumococci before and after the introduction of pneumococcal conjugate vaccination in Germany. Int J Med Microbiol. 2015; 305(7): 776-83. PubMed Abstract | Publisher Full Text

22. F Tomczyk S, Lynfield R, Schaffner W, et al.: Prevention of AntibioticNonsusceptible Invasive Pneumococcal Disease With the 13-Valent Pneumococcal Conjugate Vaccine. Clin Infect Dis. 2016; 62(9): 1119-25. PubMed Abstract | Publisher Full Text | F1000 Recommendation

23. Myint TT, Madhava H, Balmer P, et al:: The impact of 7-valent pneumococcal conjugate vaccine on invasive pneumococcal disease: a literature review. Adv Ther. 2013; 30(2): 127-51.

PubMed Abstract | Publisher Full Text

24. Griffin MR, Zhu Y, Moore MR, et al:: U.S. hospitalizations for pneumonia after a decade of pneumococcal vaccination. N Engl J Med. 2013; 369(2): 155-63. PubMed Abstract | Publisher Full Text | Free Full Text

25. Simonsen L, Taylor RJ, Schuck-Paim C, et al.: Effect of 13-valent pneumococcal conjugate vaccine on admissions to hospital 2 years after its introduction in the USA: a time series analysis. Lancet Respir Med. 2014; 2(5): 387-94. PubMed Abstract | Publisher Full Text

26. Chavanet P: Pneumococcus infections: is the burden still as heavy? Med Mal Infect. 2012; 42(4): 149-53.

PubMed Abstract | Publisher Full Tex

27. Weinberger DM, Malley R, Lipsitch M: Serotype replacement in disease after pneumococcal vaccination. Lancet. 2011; 378(9807): 1962-73. PubMed Abstract | Publisher Full Text | Free Full Text

28. Cillóniz C, Amaro R, Torres A: Pneumococcal vaccination. Curr Opin Infect Dis. 2016; 29(2): 187-96.

PubMed Abstract | Publisher Full Text

29. van der Linden M, Perniciaro S, Imöhl M: Increase of serotypes $15 A$ and 23B in IPD in Germany in the PCV13 vaccination era. BMC Infect Dis. 2015; 15: 207. PubMed Abstract | Publisher Full Text | Free Full Text 
30. Waight PA, Andrews NJ, Ladhani SN, et al.: Effect of the 13-valent pneumococcal conjugate vaccine on invasive pneumococcal disease in England and Wales 4 years after its introduction: an observational cohort study. Lancet Infect Dis. 2015; 15(5): 535-43.

PubMed Abstract | Publisher Full Text

31. F Chalmers JD, Campling J, Dicker A, et al.: A systematic review of the burden of vaccine preventable pneumococcal disease in UK adults. BMC Pulm Med. 2016; 16(1): 77.

PubMed Abstract | Publisher Full Text | Free Full Text | F1000 Recommendation

32. Sanz Herrero F, Blanquer Olivas J: Microbiology and risk factors for communityacquired pneumonia. Semin Respir Crit Care Med. 2012; 33(3): 220-31. PubMed Abstract | Publisher Full Text

33. Feldman C, Anderson R: The role of Streptococcus pneumoniae in CAP. Semin Respir Crit Care Med. In press.

34. Krone CL, van de Groep K, Trzciński K, et al.: Immunosenescence and pneumococcal disease: an imbalance in host-pathogen interactions. Lancet Respir Med. 2014; 2(2): 141-53. PubMed Abstract | Publisher Full Text

35. Nuorti JP, Butler JC, Farley MM, et al.: Cigarette smoking and invasive pneumococcal disease. Active Bacterial Core Surveillance Team. N Engl J Med. 2000; 342(10): 681-9.

PubMed Abstract | Publisher Full Text

36. Bello S, Menéndez R, Torres A, et al:: Tobacco smoking increases the risk for death from pneumococcal pneumonia. Chest. 2014; 146(4): 1029-37. PubMed Abstract | Publisher Full Text

37. Feldman C, Anderson R: Bacterial Respiratory Infections Complicating Human Immunodeficiency Virus. Semin Respir Crit Care Med. 2016; 37(2): 214-29. PubMed Abstract | Publisher Full Text

38. Boikos C, Quach C: Risk of invasive pneumococcal disease in children and adults with asthma: a systematic review. Vaccine. 2013; 31(42): 4820-6. PubMed Abstract | Publisher Full Text

39. Torres A, Peetermans WE, Viegi G, et al:: Risk factors for community-acquired pneumonia in adults in Europe: a literature review. Thorax. 2013; 68(11): 1057-65. PubMed Abstract | Publisher Full Text | Free Full Text

40. Torres A, Blasi F, Dartois N, et al:: Which individuals are at increased risk of pneumococcal disease and why? Impact of COPD, asthma, smoking, diabetes, and/or chronic heart disease on community-acquired pneumonia and invasive pneumococcal disease. Thorax. 2015; 70(10): 984-9. PubMed Abstract | Publisher Full Text | Free Full Text

41. Steel HC, Cockeran R, Anderson R, et al:: Overview of communityacquired pneumonia and the role of inflammatory mechanisms in the immunopathogenesis of severe pneumococcal disease. Mediators Inflamm. 2013; 2013: 490346.

PubMed Abstract | Publisher Full Text | Free Full Text

42. Feldman C, Anderson R: Review: current and new generation pneumococcal vaccines. J Infect. 2014; 69(4): 309-25. PubMed Abstract | Publisher Full Text

43. Geno KA, Gilbert GL, Song JY, et al:: Pneumococcal Capsules and Their Types: Past, Present, and Future. Clin Microbiol Rev. 2015; 28(3): 871-99. PubMed Abstract | Publisher Full Text | Free Full Text

44. Musher DM: Pneumococcal vaccination in adults. UpToDate. accessed July 7 , 2016. Reference Source

45. Jardine A, Menzies RI, Mclntyre PB: Reduction in hospitalizations for pneumonia associated with the introduction of a pneumococcal conjugate vaccination schedule without a booster dose in Australia. Pediatr Infect Dis $\mathrm{J}$. 2010; 29(7): 607-12

PubMed Abstract | Publisher Full Text

46. Afonso ET, Minamisava R, Bierrenbach AL, et al.: Effect of 10-valent pneumococcal vaccine on pneumonia among children, Brazil. Emerging Infect Dis. 2013; 19(4): 589-97.

PubMed Abstract | Publisher Full Text | Free Full Text

47. F Sgambatti S, Minamisava R, Bierrenbach AL, et al.: Early impact of 10-valent pneumococcal conjugate vaccine in childhood pneumonia hospitalizations using primary data from an active population-based surveillance. Vaccine. 2016; 34(5): 663-70.

PubMed Abstract | Publisher Full Text | F1000 Recommendation

48. Fernández V JP, Goecke HC, von Borries C, et al:: [Incidence of admissions due to pneumonia in children under 24 months old before and after the introduction of the 10-valent pneumococcal conjugate vaccine into the National Immunization Program of Chile]. Rev Chil Pediatr. 2015; 86(3): 168-72. PubMed Abstract | Publisher Full Text

49. Harboe ZB, Dalby T, Weinberger DM, et al.: Impact of 13-valent pneumococcal conjugate vaccination in invasive pneumococcal disease incidence and mortality. Clin Infect Dis. 2014; 59(8): 1066-73.

PubMed Abstract | Publisher Full Text

50. Lepoutre A, Varon E, Georges S, et al.: Impact of the pneumococcal conjugate vaccines on invasive pneumococcal disease in France, 2001-2012. Vaccine. 2015; 33(2): 359-66.

PubMed Abstract | Publisher Full Text

51. Chacon-Cruz E, Rivas-Landeros RM, Volker-Soberanes ML: Early trends in invasive pneumococcal disease in children following the introduction of 13-valent pneumococcal conjugate vaccine: results from eight years of active surveillance in a Mexican hospital. Ther Adv Vaccines. 2014; 2(6): 155-8. PubMed Abstract | Publisher Full Text | Free Full Text

52. Vogel AM, Trenholme AA, Stewart JM, et al:: Impact of pneumococcal vaccine on hospital admission with lower respiratory infection in children resident in South Auckland, New Zealand. N Z Med J. 2013; 126(1378): 26-35. PubMed Abstract

53. Becker-Dreps S, Amaya E, Liu L, et al:: Changes in childhood pneumonia and infant mortality rates following introduction of the 13-valent pneumococcal conjugate vaccine in Nicaragua. Pediatr Infect Dis J. 2014; 33(6): 637-42. PubMed Abstract | Publisher Full Text

54. Madhi SA, Bamford L, Ngcobo N: Effectiveness of pneumococcal conjugate vaccine and rotavirus vaccine introduction into the South African public immunisation programme. S Afr Med J. 2014; 104(3 Suppl 1): 228-34. PubMed Abstract | Publisher Full Text

55. Grijalva CG, Nuorti JP, Arbogast PG, et al.: Decline in pneumonia admissions after routine childhood immunisation with pneumococcal conjugate vaccine in the USA: a time-series analysis. Lancet. 2007; 369(9568): 1179-86. PubMed Abstract | Publisher Full Text

56. Simonsen L, Taylor RJ, Young-Xu Y, et al:: Impact of pneumococcal conjugate vaccination of infants on pneumonia and influenza hospitalization and mortality in all age groups in the United States. MBio. 2011; 2(1): e00309-10. PubMed Abstract | Publisher Full Text | Free Full Text

57. Moore MR, Link-Gelles R, Schaffner W, et al.: Effect of use of 13-valent pneumococcal conjugate vaccine in children on invasive pneumococca disease in children and adults in the USA: analysis of multisite, populationbased surveillance. Lancet Infect Dis. 2015; 15(3): 301-9. PubMed Abstract | Publisher Full Text | Free Full Text

58. Keller LE, Robinson DA, McDaniel LS: Nonencapsulated Streptococcus pneumoniae: Emergence and Pathogenesis. MBio. 2016; 7(2): e01792. PubMed Abstract | Publisher Full Text | Free Full Text

59. Nelson AL, Roche AM, Gould JM, et al:: Capsule enhances pneumococcal colonization by limiting mucus-mediated clearance. Infect Immun. 2007; 75(1): 83-90.

PubMed Abstract | Publisher Full Text | Free Full Text

60. Park IH, Kim K, Andrade AL, et al:: Nontypeable pneumococci can be divided into multiple cps types, including one type expressing the novel gene $p s p K$. MBio. 2012; 3(3): pii: e00035-12.

PubMed Abstract | Publisher Full Text | Free Full Text

61. Hammerschmidt S, Wolff S, Hocke A, et al:: Illustration of pneumococcal polysaccharide capsule during adherence and invasion of epithelial cells. Infect Immun. 2005; 73(8): 4653-67.

PubMed Abstract | Publisher Full Text | Free Full Text

62. Keller LE, Jones CV, Thornton JA, et al.: PspK of Streptococcus pneumoniae increases adherence to epithelial cells and enhances nasopharyngeal colonization. Infect Immun. 2013; 81(1): 173-81. PubMed Abstract | Publisher Full Text | Free Full Text

63. $\mathrm{F}$ Keller LE, Bradshaw JL, Pipkins $\mathrm{H}$, et al:: Surface Proteins and Pneumolysin of Encapsulated and Nonencapsulated Streptococcus pneumoniae Mediate Virulence in a Chinchilla Model of Otitis Media. Front Cell Infect Microbiol. 2016; 6: 55 . PubMed Abstract | Publisher Full Text | Free Full Text | F1000 Recommendation

64. Moscoso M, García E, López R: Biofilm formation by Streptococcus pneumoniae: role of choline, extracellular DNA, and capsular polysaccharide in microbial accretion. J Bacteriol. 2006; 188(22): 7785-95. PubMed Abstract | Publisher Full Text | Free Full Text

65. Schaffner TO, Hinds J, Gould KA, et al:: A point mutation in cpsE renders Streptococcus pneumoniae nonencapsulated and enhances its growth, adherence and competence. BMC Microbiol. 2014; 14: 210 PubMed Abstract | Publisher Full Text | Free Full Text

66. F Musher DM, Rueda AM, Kaka AS, et al.: The association between pneumococcal pneumonia and acute cardiac events. Clin Infect Dis. 2007; 45(2): 158-65

PubMed Abstract | Publisher Full Text | F1000 Recommendation

67. Brown AO, Mann B, Gao G, et al:: Streptococcus pneumoniae translocates into the myocardium and forms unique microlesions that disrupt cardiac function. PLOS Pathog. 2014; 10(9): e1004383. PubMed Abstract | Publisher Full Text | Free Full Text

68. F Orihuela CJ, Mahdavi J, Thornton J, et al.: Laminin receptor initiates bacterial contact with the blood brain barrier in experimental meningitis models. J Clin Invest. 2009; 119(6): 1638-46.

PubMed Abstract | Publisher Full Text | Free Full Text | F1000 Recommendation

69. Mook-Kanamori BB, Geldhoff M, van der Poll T, et al:: Pathogenesis and pathophysiology of pneumococcal meningitis. Clin Microbiol Rev. 2011; 24(3): 557-91

PubMed Abstract | Publisher Full Text | Free Full Text

70. F Alhamdi Y, Neill DR, Abrams ST, et al:: Circulating Pneumolysin Is a Potent Inducer of Cardiac Injury during Pneumococcal Infection. PLOS Pathog. 2015; 11(5): e1004836.

PubMed Abstract | Publisher Full Text | Free Full Text | F1000 Recommendation

71. F Alhamdi Y, Zi M, Abrams ST, et al.: Circulating Histone Concentrations Differentially Affect the Predominance of Left or Right Ventricular Dysfunction in Critical IIIness. Crit Care Med. 2016; 44(5): e278-88.

PubMed Abstract | Publisher Full Text | F1000 Recommendation 
72. Ohkuni $\mathrm{H}$, Nagamune $\mathrm{H}$, Ozaki $\mathrm{N}$, et al:: Characterization of recombinant Streptococcus mitis-derived human platelet aggregation factor. APMIS. 2012; 120(1): 56-71.

PubMed Abstract | Publisher Full Text

73. Nel JG, Durandt C, Mitchell TJ, et al:: Pneumolysin Mediates Platelet Activation In Vitro. Lung. 2016; 194(4): 589-93. PubMed Abstract | Publisher Full Tex

74. F Gilley RP, González-Juarbe N, Shenoy AT, et al.: Infiltrated Macrophages Die of Pneumolysin-Mediated Necroptosis following Pneumococcal Myocardial Invasion. Infect Immun. 2016; 84(5): 1457-69.

PubMed Abstract | Publisher Full Text | Free Full Text | F1000 Recommendation

75. F Rai P, Parrish M, Tay IJ, et al:: Streptococcus pneumoniae secretes hydrogen peroxide leading to DNA damage and apoptosis in lung cells. Proc Natl Acad Sci U S A. 2015; 112(26): E3421-30.

PubMed Abstract | Publisher Full Text | Free Full Text | F1000 Recommendation

76. F Canli Ö, Alankuș YB, Grootjans S, et al:: Glutathione peroxidase 4 prevents necroptosis in mouse erythroid precursors. Blood. 2016; 127(1): 139-48. PubMed Abstract | Publisher Full Text | Free Full Text | F1000 Recommendation

77. Saleh M, Bartual SG, Abdullah MR, et al:: Molecular architecture of Streptococcus pneumoniae surface thioredoxin-fold lipoproteins crucial for extracellular oxidative stress resistance and maintenance of virulence. EMBO Mol Med. 2013; 5(12): 1852-70.

PubMed Abstract | Publisher Full Text | Free Full Text

78. F Hsieh YC, Lin TL, Lin CM, et al:: Identification of PbIB mediating galactosespecific adhesion in a successful Streptococcus pneumoniae clone. Sci Rep. 2015; 5: 12265

PubMed Abstract | Publisher Full Text | Free Full Text | F1000 Recommendation

79. F Escolano-Martínez MS, Domenech A, Yuste J, et al:: DiiA is a novel dimorphic cell wall protein of Streptococcus pneumoniae involved in invasive disease. J Infect. 2016; 73(1): 71-81.

PubMed Abstract | Publisher Full Text | F1000 Recommendation

80. F Robb M, Robb CS, Higgins MA, et al: A Second $\beta$-Hexosaminidase Encoded in the Streptococcus pneumoniae Genome Provides an Expanded Biochemical Ability to Degrade Host Glycans. J Biol Chem. 2015; 290(52): 30888-900. PubMed Abstract | Publisher Full Text | Free Full Text | F1000 Recommendation

81. F Terra VS, Zhi X, Kahya HF, et al:: Pneumococcal 6-Phospho- $\beta$-Glucosidase (BglA3) Is Involved in Virulence and Nutrient Metabolism. Infect Immun. 2015; 84(1): 286-92.

PubMed Abstract | Publisher Full Text | Free Full Text | F1000 Recommendation

82. F Romero-Espejel ME, Rodríguez MA, Chávez-Munguía B, et al.: Characterization of Spbhp-37, a Hemoglobin-Binding Protein of Streptococcus pneumoniae. Front Cell Infect Microbiol. 2016; 6: 47 .

PubMed Abstract | Publisher Full Text | Free Full Text | F1000 Recommendation

83. F Mohan S, Hertweck C, Dudda A, et al:: Tuf of Streptococcus pneumoniae is a surface displayed human complement regulator binding protein. $\mathrm{Mol}$ Immunol. 2014; 62(1): 249-64.

PubMed Abstract | Publisher Full Text | F1000 Recommendation

84. F Rai AN, Thornton JA, Stokes J, et al:: Polyamine transporter in Streptococcus pneumoniae is essential for evading early innate immune responses in pneumococcal pneumonia. Sci Rep. 2016; 6: 26964 PubMed Abstract | Publisher Full Text | Free Full Text | F1000 Recommendation

85. F Chang CY, Li BR, Li YK: An I-ascorbate-6-phosphate lactonase from Streptococcus pneumoniae ATCC 49136 strain reveals metallo- $\beta$-lactamase activity. Int J Antimicrob Agents. 2016; 47(5): 416-8.

PubMed Abstract | Publisher Full Text | F1000 Recommendation

86. F Garin N, Genné D, Carballo S, et al:: $\beta$-Lactam monotherapy vs $\beta$-lactammacrolide combination treatment in moderately severe community-acquired pneumonia: a randomized noninferiority trial. JAMA Intern Med. 2014; 174(12): pneumonia:

PubMed Abstract | Publisher Full Text | F1000 Recommendation

87. F Lee JS, Giesler DL, Gellad WF, et al:: Antibiotic Therapy for Adults Hospitalized With Community-Acquired Pneumonia: A Systematic Review. JAMA. 2016; 315(6): 593-602.

PubMed Abstract | Publisher Full Text | F1000 Recommendation

88. F Gattarello S: What Is New in Antibiotic Therapy in Community-Acquired Pneumonia? An Evidence-Based Approach Focusing on Combined Therapy. Curr Infect Dis Rep. 2015; 17(10): 501

PubMed Abstract | Publisher Full Text | F1000 Recommendation

89. F Gattarello S, Borgatta B, Solé-Violán J, et al.: Decrease in mortality in severe community-acquired pneumococcal pneumonia: impact of improving antibiotic strategies (2000-2013). Chest. 2014; 146(1): 22-31. PubMed Abstract | Publisher Full Text | F1000 Recommendation

90. $\mathrm{F}$ Gattarello S, Lagunes L, Vidaur L, et al:: Improvement of antibiotic therapy and ICU survival in severe non-pneumococcal community-acquired pneumonia: a matched case-control study. Crit Care. 2015; 19: 335 PubMed Abstract | Publisher Full Text | Free Full Text | F1000 Recommendation

91. F Sligl WI, Asadi L, Eurich DT, et al.: Macrolides and mortality in critically ill patients with community-acquired pneumonia: a systematic review and metaanalysis. Crit Care Med. 2014; 42(2): 420-32.

PubMed Abstract | Publisher Full Text | F1000 Recommendation

92. F McFarlane A, Sligl W: The Value of Macrolide-Based Regimens for Community-Acquired Pneumonia. Curr Infect Dis Rep. 2015; 17(12): 50. PubMed Abstract | Publisher Full Text | F1000 Recommendation

93. F Emmet O'Brien M, Restrepo MI, Martin-Loeches I: Update on the combination effect of macrolide antibiotics in community-acquired pneumonia. Respir Investig. 2015; 53(5): 201-9.

PubMed Abstract | Publisher Full Text | F1000 Recommendation

94. $\mathrm{F}$ Trac MH, McArthur E, Jandoc R, et al:: Macrolide antibiotics and the risk of ventricular arrhythmia in older adults. CMAJ. 2016; 188(7): E120-9. PubMed Abstract | Publisher Full Text | Free Full Text | F1000 Recommendation

95. Wunderink RG, Mandell L: Adjunctive therapy in community-acquired pneumonia. Semin Respir Crit Care Med. 2012; 33(3): 311-8.

PubMed Abstract | Publisher Full Text

96. Faverio P, Restrepo MI: Non-antibiotic therapies for CAP. In Eur Respir Monogr. Edited by Chalmers J, Pletz MA, Aliberti S. United Kingdom: European Respiratory Society; 2014; 63: 219-233.

97. Salih W, Short PM, Schembri S: Macrolides as anti-inflammatory agents in CAP. In Eur Respir Monogr. Edited by Chalmers J, Pletz MA, Aliberti S. United Kingdom: European Respiratory Society; 2014; 63: 243-255.

98. F Blum CA, Nigro N, Briel M, et al:: Adjunct prednisone therapy for patients with community-acquired pneumonia: a multicentre, double-blind, randomised, placebo-controlled trial. Lancet. 2015; 385(9977): 1511-8. PubMed Abstract | Publisher Full Text | F1000 Recommendation

99. F Siemieniuk RA, Meade MO, Alonso-Coello P, et al.: Corticosteroid Therapy for Patients Hospitalized With Community-Acquired Pneumonia: A Systematic Review and Meta-analysis. Ann Intern Med. 2015; 163(7): 519-28. PubMed Abstract | Publisher Full Text | F1000 Recommendation

100. Feldman $\mathrm{C}$, Anderson R: Corticosteroids in the adjunctive therapy of community-acquired pneumonia: an appraisal of recent meta-analyses of clinical trials. J Thorac Dis. 2016; 8(3): E162-71. PubMed Abstract | Publisher Full Text | Free Full Text

101. Feldman $\mathrm{C}$, Anderson R: Community-acquired pneumonia: still a major burden of disease. Curr Opin Crit Care. 2016; 22(5): 477-84. PubMed Abstract | Publisher Full Text

102. Ludwig $E$, Bonanni $P$, Rohde $G$, et al:: The remaining challenges of pneumococcal disease in adults. Eur Respir Rev. 2012; 21(123): 57-65. PubMed Abstract | Publisher Full Text

103. Mongardon N, Max A, Bouglé A, et al:: Epidemiology and outcome of severe pneumococcal pneumonia admitted to intensive care unit: a multicenter study. Crit Care. 2012; 16(4): R155.

PubMed Abstract | Publisher Full Text | Free Full Text

104. F Naucler P, Darenberg J, Morfeldt E, et al:: Contribution of host, bacterial factors and antibiotic treatment to mortality in adult patients with bacteraemic pneumococcal pneumonia. Thorax. 2013; 68(6): 571-9. PubMed Abstract | Publisher Full Text | F1000 Recommendation

105. Burgos J, Luján M, Larrosa MN, et al:: Risk factors for respiratory failure in pneumococcal pneumonia: the importance of pneumococcal serotypes. Eur Respir J. 2014; 43(2): 545-53.

PubMed Abstract | Publisher Full Text

106. F Gili-Miner M, López-Méndez J, Béjar-Prado L, et al.: Alcohol Use Disorders and Community-Acquired Pneumococcal Pneumonia: Associated Mortality, Prolonged Hospital Stay and Increased Hospital Spending. Arch Bronconeumol. 2015; 51(11): 564-70.

PublMed Abstract | Publisher Full Text | F1000 Recommendation

107. Ruiz LA, Zalacain R, Capelastegui A, et al.: Bacteremic pneumococcal pneumonia in elderly and very elderly patients: host- and pathogen-related factors, process of care, and outcome. J Gerontol A Biol Sci Med Sci. 2014; 69(8): 1018-24.

PubMed Abstract | Publisher Full Text

108. F Burgos J, Luján M, Larrosa MN, et al:: The problem of early mortality in pneumococcal pneumonia: a study of risk factors. Eur Respir J. 2015; 46(2): $561-4$.

PubMed Abstract | Publisher Full Text | F1000 Recommendation

109. F Beatty JA, Majumdar SR, Tyrrell GJ, et al.: Current Smoking and Reduced Mortality in Bacteremic Pneumococcal Pneumonia: A Population-Based Cohort Study. Chest. 2016; pii: S0012-3692(16)48803-3. PubMed Abstract | Publisher Full Text | F1000 Recommendation

110. F Grau I, Ardanuy C, Cubero M, et al.: Declining mortality from adult pneumococcal infections linked to children's vaccination. $J$ Infect. 2016; 72(4) $439-49$.

PubMed Abstract | Publisher Full Text | F1000 Recommendation 


\section{Open Peer Review}

\section{Current Peer Review Status:}

\section{Editorial Note on the Review Process}

Faculty Reviews are review articles written by the prestigious Members of Faculty Opinions. The articles are commissioned and peer reviewed before publication to ensure that the final, published version is comprehensive and accessible. The reviewers who approved the final version are listed with their names and affiliations.

\section{The reviewers who approved this article are:}

\section{Version 1}

\section{Tobias Moser}

Center for Infectious Diseases and Infection Control, Jena University Hospital, Jena, Germany Competing Interests: Mathias Pletz has acted on the advisory board and/or speaker's bureau of pharmaceutical companies manufacturing or marketing antibiotics and pneumococcal conjugate vaccines (Astrazeneca, Pfizer, Novartis, MSD, Basilea).

\section{Daniel Musher}

${ }^{1}$ Departments of Medicine and Molecular Virology and Microbiology, Baylor College of Medicine, Houston, TX, USA

2 Medical Care Line (Infectious Disease Section), Michael E. DeBakey Veterans Affairs Medical Center, Houston, TX, USA

Competing Interests: No competing interests were disclosed.

The benefits of publishing with F1000Research:

- Your article is published within days, with no editorial bias

- You can publish traditional articles, null/negative results, case reports, data notes and more

- The peer review process is transparent and collaborative

- Your article is indexed in PubMed after passing peer review

- Dedicated customer support at every stage

For pre-submission enquiries, contact research@f1000.com 